\title{
PENGARUH BOOK-TAX DIFFERENCES, UKURAN PERUSAHAAN DAN LABA SEBELUM PAJAK TAHUN BERJALAN TERHADAP PERSISTENSI LABA PADA PERUSAHAAN MANUFAKTUR YANG TERDAFTAR DI BURSA EFEK INDONESIA TAHUN 2011-2015
}

\author{
Bella Imanda Shefira, R. Ery Wibowo Agung S , Alwiyah \\ Prodi Akuntansi Universitas Muhammadiyah Semarang
}

Riwayat Artikel: Dikirim April 2018; Diterima Maret 2018 ; Diterbitkan Maret 2018

Tujuan penelitian ini adalah untuk mengetahui pengaruh perbedaan permanen, perbedaan temporer, ukuran perusahaan dan laba sebelum pajak tahun berjalan secara simultan maupun parsial terhadap persistensi laba perusahaan manufaktur yang terdaftar di Bursa Efek Indonesia tahun 2011-2015.

Variabel independen yang digunakan dalam penelitian ini adalah perbedaan permanen, perbedaan temporer, ukuran perusahaan dan laba'/ sebelum pajak tahun berjalan, sedangkan variabel dependennya adalah persistensi laba.Populasi yang digunakan dalam penelitian ini adalah seluruh perusahaan manufaktur yang terdaftar di Bursa Efek Indonesia yang berjumlah 101 perusahaan.Metode pengambilan sampel yang digunakan adalah teknik purposive sampling. Sampel yang memenuhi kriteria adalah 25 perusahaan.Data yang digunakan dalam penelitian ini adalah data sekunder.Alat yang digunakan dalam penelitian ini adalah regresi linier berganda.

Hasil penelitian ini menunjukkan bahwa perbedaan permanen secara parsial tidak berpengaruh signifikan terhadap persistensi laba, sedangkan perbedaan temporer, ukuran perusahaan dan laba sebelum pajak tahun berjalan berpengaruh signifikan terhadap persistensi laba. Secara simultan perbedaan permanen, perbedaan temporer, ukuran perusahaan dan laba sebelum pajak tahun berjalan berpengaruh signifikan terhadap persistensi laba dengan tingkat signifikan $0,000<0,05$. Nilai Adjusted R2 menunjukkan hasil sebesar 82,1\% persistensi laba dipengaruhi oleh perbedaan permanen, perbedaan temporer, ukuran perusahaan dan laba sebelum pajak tahun berjalan, sedangkan sisanya sebesar 17,9\%dipengaruhi oleh variabel lain diluar penelitian ini.

Kata kunci: Perbedaan Permanen, Perbedaan Temporer, Ukuran Perusahaan, Laba Sebelum Pajak Tahun Berjalan, Persistensi Laba 


\section{PENDAHULUAN}

Laporan keuangan yang dipublikasikan merupakan sumber informasi sangat penting yang dibutuhkan oleh sebagian besar pemakai laporan serta pihak yang berkepentingan dengan emiten untuk mendukung pengambilan keputusan. Fokus utama laporan keuangan adalah informs mengenai laba dan komponennya. Laba menjadi salah satu parameter kinerja perusahaan yang mendapat perhatian utama dari investor dan kreditur. Menurut Fanani (2010) laba dikatakan persisten jika laba dapat mecerminkankeberlanjutan dimasa yang akan datang dan apabila laba tahun berjalan dapat menjadi indikator yang bai untuk menilai laba dimasa datang.

Salah satu isu yang berkembang adalah tentang perbedaan antara laba akuntansi dan laba fiskal (book-tax differences).Perbedaan ini disebabkan karena adanya peraturan yang berbeda antara PSAK dan Undang-undang Perpajakan.Perbedaan ini disebabkan perbedaan tujuan dan kepentingan masing-masing pengguna informasi laba tersebut.Menurut Resmi perbedaan antara kedua kebijakan tersebut tidak mengharuskan perusahaan membuat dua laporan keuangan dalam satu periode, hanya saja mengharuskan peruahaan melakukan koreksi fiskal yang menyebabkan adanya perbedaan permanen dan perbedaan temporer.

$$
\text { Menurut Djamaluddin }
$$

berpendapat bahwa book-tax differences dapat memberikan informasi mengenai kualitas laba. Beberapa literature menyebutkan bahwa terdapat faktor lain yang dapat mempengaruhi persistensi laba yaitu ukuran perusahaan yang tercermin dari totak aktiva yang dimiliki perusahaan. Selain itu, laba sebelum pajak tahun berjalan juga menjadi indikator yang mempengaruhi persistensi laba, hal ini sesuai dengan penelitian yang dilakukan oleh Chowijaya (2014).

Berdasarkan latar belakang diatas maka dapat dirumuskan latar belakang sebagai berikut:

1. Apakah perbedaan permanen secara parsial berpengaruh terhadap persistensi laba pada perusahaan manufaktur yang terdaftar di BEI tahun 2011-2015?

2. Apakah perbedaan temporer secara parsial berpengaruh terhadap persistensi laba pada perusahaan manufaktur yang terdaftar di BEI tahun 2011-2015?

3. Apakah ukuran perusahaan secara parsial berpengaruh terhadap persistensi laba pada perusahaan 
manufaktur yang terdaftar di BEI tahun 2011-2015?

4. Apakah laba sebelum pajak tahun berjalan secara parsial berpengaruh terhadap persistensi laba pada perusahaan manufaktur yang terdaftar di BEI tahun 2011-2015?

5. Apakah perbedaan permanen, perbedaan temporer, ukuran perusahaan dan laba sebelum pajak tahun berjalan secara simultan berpengaruh terhadap persistensi laba pada perusahaan manufaktur yang terdaftar di BEI tahun 2011-2015?

\section{LANDASAN TEORI}

Teori Keagenan (Agency Theory)

\section{Laporan Keuangan}

Menurut PSAK No.1 (2015) laporan keuangan adalah penyajian terstruktur dari posisi keuangan dan kinerja keuangan suatu entitas.Laporan keuangan disusun sebagai bentuk pertanggungjawaban manajemen kepada pemilik perusahaan atas sumber daya yang dipercayakan kepadanya dan atas kinerja yang telah dicapainya.Laporan keuangan terdiri dari neraca, laba rugi, perubahan ekuitas dan arus kas.Menurut IAI (2009) laporan keuangan memiliki empat karakteristik kualitatif pokok yaitu dapat dipahami, relevan, keandalan dan dapat diperbandingkan.

\section{Persistensi Laba}

Djamaluddin (2008) persistensi laba merupakan revisi dalam laba akuntansi yang diharapkan dimasa datang yang diimplikasikan oleh inovasi laba tahun berjalan.Laba yang berkualitas adalah laba yang persisten atau laba yang berkelanjutan, lebih bersifat permanen dan tidak transitori. Persada (2010) mengukur persistensi laba dengan menggunakan koefisien regresi antara laba akuntansi sebelum pajak tahun berjalan dikurangi dengan laba sebelum pajak tahun sebelumnya dibagi dengan total asset yang dimiliki oleh perusahaan pada tahun berjalan.

\section{Book-Tax Differences}

Manajemen menghitung laba perusahaan setiap tahunnya untuk dua tujuan yaitu tujuan untuk pelaporan keuangan dan pelaporan pajak.Penyebab perbedaan laporan keuangan komersial dan fiskal (book-tax differences) adalah karena terdapat perbedaan prinsip akuntansi, perbedaan metode dan prosedur akuntansi, perbedaan pengakuan penghasilan dan biaya serta perbedaan 
perlakuan penghasilan dan biaya (Resmi, 2011).

Perbedaan antara laporan keuangan komersial dan fiskal tidak mengharuskan perusahaan untuk menyusun dua laporan sekaligus setiap tahunnya, hanya saja mengharuskan perusahaan untuk melakukan rekonsiliasi fiskal yang menyebabkan adanya perbedaan permanen dan perbedaan temporer.

\section{Perbedaan Temporer}

Menurut Harnanto (2003) perbedaan temporer adalah perbedaan antara dasar pengenaan pajak dari suatu aktiva atau kewajiban dengan nilai tercatat aktiva atau kewajiban tersebut yang akan berakibat pada kenaikan atau berkurangnya laba fiskal periode mendatang pada saat nilai tercatat aktiva dipulihkan atau nilai tercatat kewajiban diselesaikan atau dilunasi. Perbedaan temporer terjadi karena perbedaanwaktu pengakuan pendapatan dan biaya antara pajak dengan akuntansi. Menurut Zain (2008) penyebab perbedaan temporer adalah sebagai berikut:

1. Metode penyusutan dan amortisasi

2. Metode penilaian persediaan

3. Penghapusan piutang

\section{Perbedaan Permanen}

Perbedaan permanen adalah perbedaan yang terjadi karena peraturan perpajakan menghitung laba fiskal berbeda dengan perhitungan menurut standar akuntansi keuangan tanpa ada koreksi dikemudian hari.Misalnya, bunga deposito diakui sebagai pendapatan dalam laba akuntansi tetapi tidak diakui sebagai pendapatan dalam laba fiskal.Penghasilan dalam bentuk natura, bunga sumbangan dan lain sebagainya. Menurut Persada (2010) perbedaan permanen sebagai indikator book-tax differences didapat dari laporan keuangan pada bagian rekonsiliasi fiskal dan dibagi dengan total aktiva.

Perbedaan permanen terjadi akibat perbedaan pengakuan penghasilan dan biaya yang terdapat pada:

1. Penghasilan yang telah dipotong $\mathrm{PPh}$ final

2. Penghasilan yang bukan merupaan objek pajak

3. Pengeluaran yang tidak termasuk dalam deductible expense dan termasuk dalam non deductible expense.

\section{Ukuran Perusahaan}


Ukuran perusahaan merupakan ukuran atau besarnya aset yang dimiliki perusahaan. Ukuran perusahaan dapat digunakan sebagai proksi ketidakpastian terhadap keadaan perusahaan dimasa yang akan datang.

\section{Laba Sebelum Pajak Tahun Berjalan}

Menurut Chowijaya (2014) laba sebelum pajak tahun berjalan atau laba akuntansi merupakan laba yang dihasilkan dari kegiatan utama perusahaan didalam satu periode tertentu, baik penghasilan maupun beban yang dihitung berdasarkan aturan standar akuntansi yang berlaku.

\section{Aktiva}

Menurut Yusuf (2012) aktiva atau asset merupakan sumber-sumber ekonomi yang dimiliki perusahaan yang biasanya dinyatakan dalam satuan uang.Aset digolongkan menjadi dua yaitu aset lancar dan aset tidak lancar.

\section{Kerangka Pemikiran}

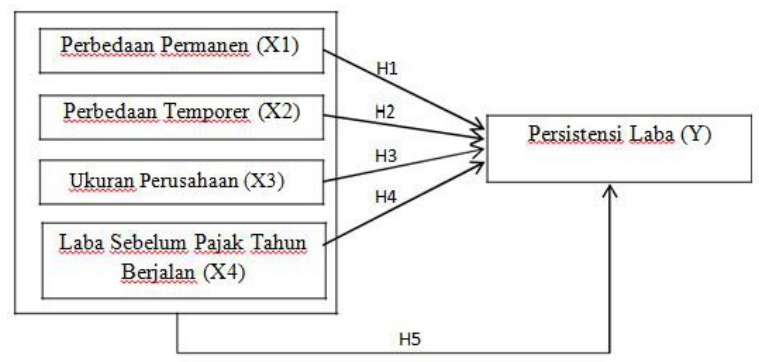

H1 : Perbedaan permanen secara persial berpengaruh signifikan terhadap persistensi laba pada perusahaan manufaktur yang terdaftar di BEI tahun 2011-2015.

H2 : Perbedaan temporer secara persial berpengaruh signifikan terhadap persistensi laba pada perusahaan manufaktur yang terdaftar di BEI tahun 2011-2015.

H3 : Ukuran perusahaan secara persial berpengaruh signifikan terhadap persistensi laba pada perusahaan manufaktur yang terdaftar di BEI tahun 2011-2015.

H4 : Laba sebelum pajak tahun berjalan secara persial berpengaruh signifikan terhadap persistensi laba pada perusahaan manufaktur yang terdaftar di BEI tahun 2011-2015.

H5 : Perbedaan permanen, perbedaan temporer, ukuran perusahaan dan laba sebelum pajak tahun berjalan secara simultan berpengaruh signifikan terhadap persistensi laba pada perusahaan manufaktur yang terdaftar di BEI tahun 2011-2015. 


\section{METODE PENELITIAN}

\section{Variabel Penelitian}

\section{Variabel Dependen}

Persistensi Laba:

Laba sebelum pajak tahun tahun $t-l a b a$ sebelum pajak tahun tTotal Aktiva
Teknik pengambilan sampel dalam penelitian ini dilakukan dengan menggunakan purposive sampling, yaitu merupakan teknik pengambilan sampel tidak acak yang informasinya diperoleh dengan kriteria tertentu. Adapun kriteria sebagai berikut:

1. Perusahaan manufaktur yang terdaftar di BEI dan mempublikasikan laporan keuangan auditan per 31 Desember secara konsisten dan lengkap dari tahun 2011-2015.

Ukuran Perusahaan: Total Aktiva

2. Periode laporan keuangan

Laba Sebelum Pajak Tahun Berjalan

\section{Jenis dan Sumber Data}

Jenis data yang digunakan dalam penelitian ini adalah data sekunder.Data tersebut dikumpulkan, diolah $\$$ dan dipublikasikan dari situs Bursa Efek Indonesia yaitu www.idx.co.id.

\section{Metode Pengumpulan Data}

Metode pengumpulan data dalam penelitian ini adalah metode dokumentasi dan studi pustaka.

\section{Populasi dan Sampel Penelitian}

berakhir 31 Desember dan memiliki kelengkapan informasi yang terkait dengan variabel penelitian.

3. Perusahaan tidak mengalami kerugian dalam laporan keuangan umum dan laporan keuangan pajak.

\section{Teknik Analisis Data}

Teknik analisis data dalam penelitian ini terdiri dari statistic deskriptif, uji asumsi klasik (uji normalitas, multikolinearitas, heteroskedastisitas, autokorelasi), analisis regresi linear berganda dan pengujian hipotesis (koefisien determinasi, uji t dan uji F). 


\section{HASIL DAN PEMBAHASAN \\ Deskripsi Obyek Penelitian
1. Variabel dependen yaitu
persistensi laba yang merupakan
revisi laba akuntansi pada tahun
depan yang diimplikasikan oleh
laba tahun berjalan dikurangi
laba tahun sebelumnya dibagi \\ Deskripsi Obyek Penelitian
1. Variabel dependen yaitu
persistensi laba yang merupakan
revisi laba akuntansi pada tahun
depan yang diimplikasikan oleh
laba tahun berjalan dikurangi
laba tahun sebelumnya dibagi \\ Deskripsi Obyek Penelitian
persistensi laba yang merupakan
revisi laba akuntansi pada tahun
depan yang diimplikasikan oleh
laba tahun berjalan dikurangi
laba tahun sebelumnya dibagi \\ Deskripsi Obyek Penelitian
persistensi laba yang merupakan
revisi laba akuntansi pada tahun
depan yang diimplikasikan oleh
laba tahun berjalan dikurangi
laba tahun sebelumnya dibagi \\ Deskripsi Obyek Penelitian
persistensi laba yang merupakan
revisi laba akuntansi pada tahun
depan yang diimplikasikan oleh
laba tahun berjalan dikurangi
laba tahun sebelumnya dibagi \\ Deskripsi Obyek Penelitian
persistensi laba yang merupakan
revisi laba akuntansi pada tahun
depan yang diimplikasikan oleh
laba tahun berjalan dikurangi
laba tahun sebelumnya dibagi \\ Deskripsi Obyek Penelitian
persistensi laba yang merupakan
revisi laba akuntansi pada tahun
depan yang diimplikasikan oleh
laba tahun berjalan dikurangi
laba tahun sebelumnya dibagi total aktiva.}

2. Variabel independen terdiri dari perbedaan permanen, perbedaan temporer, ukuran perusahaan dan laba sebelum pajak tahun berjalan.

\section{Analisis Data}

Seleksi sampel penelitian perusahaan manufaktur yang terdaftar di Bursa Efek Indonesia tahun 2011-2015 berdasarkan kriteria adalah sebagai berikut:

\section{SE}

\begin{tabular}{|c|l|c|}
\hline No & \multicolumn{1}{|c|}{ Kriteria } & Jumlah \\
\hline 1 & $\begin{array}{l}\text { Perusahaan Manufaktur yang terdaftar di Bursa Efe Indonesia } \\
\text { tahun 2011-2015 }\end{array}$ & 101 \\
\hline 2 & $\begin{array}{l}\text { Perusahaan Manufaktur yang tidak konsisten menerbitkan } \\
\text { laporan keuangan auditan tahun 2011-2015 }\end{array}$ & $(42)$ \\
\hline 3 & $\begin{array}{l}\text { Perusahaan Manufaktur yang terdaftar di BEI sebelum 31 } \\
\text { Desember 2011 dan masih terdaftar sampai dengan 31 Desember } \\
\text { 2015 yang mengalami kerugian dalam laporan laba rugi }\end{array}$ & (34) \\
\hline 4 & $\begin{array}{l}\text { Perusahaan Manufaktur yang konsisten menerbitkan laporan } \\
\text { keuangan auditan tahun 2011-2015 dan tidak mengalami } \\
\text { kerugian dalam laporan laba rugi yang dijadikan sampel }\end{array}$ & 25 \\
\hline
\end{tabular}

TABEL 4.1

\section{KRITERIA DAN HASIL PEMILIHAN}

\section{SAMPEL}

\section{PERUSAHAAN MANUFAKTUR TAHUN 2011-2015}

Berdasarkan kriteria diatas maka perusahaan yang memenuhi syarat dalampenelitian ini sebanyak 25 perusahaan.

\section{Analisis Statistik Deskriptif}

Deskriptif data dari setiap variabel penelitian mencakup nilai maksimum, minimum, mean dan standar deviasi dilakukan dengan uji statistik deskriptif menggunakan program SPSS 21 hasilnya dapat dilihat pada tabel 4.3 berikut: 
TABEL 4.4

\section{Uji Normalitas}

One-Sample Kolmogorov-Smirnov Test

\begin{tabular}{|c|c|c|}
\hline & & $\begin{array}{l}\text { Unstandardized } \\
\text { Residual }\end{array}$ \\
\hline N & & 125 \\
\hline \multirow{3}{*}{ Normal Parameters ${ }^{a, b}$} & Mean &, 0000000 \\
\hline & Std. Deviation &, 06143497 \\
\hline & Absolute &, 109 \\
\hline \multirow[t]{2}{*}{ Most Extreme Differences } & Positive &, 109 \\
\hline & Negative &,- 069 \\
\hline Kolmogorov-SmirnovZ & & 1,219 \\
\hline Asymp. Sig. (2-tailed) & &, 102 \\
\hline \multicolumn{3}{|l|}{ a. Test distribution is Normal. } \\
\hline $\begin{array}{l}\text { b. Calculated from data. } \\
\text { Sumber- Data diolah SE }\end{array}$ & 1,2017 & \\
\hline
\end{tabular}

Berdasarkan nilai nilai signifikansi pada Uji Kolmonogorov-Smirnov diperoleh nilai $0,102>$ nilai alfa 0,05 maka asumsi kenormalan telah terpenuhi.

\section{Uji Autokorelasi} TABEL 4.5

\section{Hasil Uji Durbin-Watson}

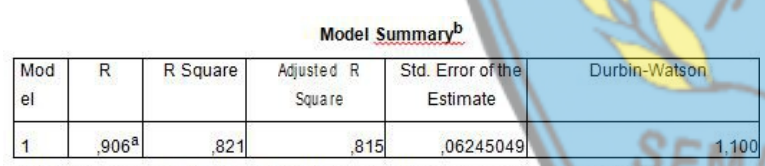

a. Predictors: (Constant), PTBIt, Beda Permanen, Beda Temporer, Ukuran Perusahaan b. Dependent Variable: Persistensi Laba

Sumber: Data diolah SPSS 21,2017

a. Predictors: (Constant), PTBIt, Beda Permanen, Beda Temporer, Ukuran Perusahaan

b. Dependent Variable: Persistensi Laba

Sumber: Data diolah SPSS 21, 2017

Berdasarkan tabel 4.5 diatas, hasil perhitungan Durbin-Watson (DW) menunjukkan angka sebesar 1,100 berdasarkan tabel DW yang menggunakan derajat kepercayaan 0,05 jumlah sampel 125 dan jumlah variable independen ada empat, maka akan didapatkan nilai batas bawah (dL) 1,6426 dan batas atas (dU) 1.7745. Jadi DW $1,100<(4-\mathrm{dU}) 2,2255$. Menurut

ketentuan uji Durbin-Watson, dapat disimpulkan bahwa tidak terdapat autokorelasi.

\section{Uji Multikolinieritas}

Uji multikolinieritas adalah uji untuk mengetahui bahwa ada atau tidaknya hubungan linear antar variabel independen. Berikut hasil uji multikolinieritas melalui SPSS 21: 
disimpulkan tidak ada korelasi antar variabel independen (bebas) atau tidak terjadi multikolineritas.Model regresi yang baik seharusnya tidak terjadi korelasi diantara variabel independen (Ghozali, 2011).

\section{Uji Heteroskedastisitas}

\section{TABEL 4.7}

Uji Glejser

\begin{tabular}{|c|c|c|c|c|c|}
\hline \multicolumn{6}{|c|}{ Coefficients ${ }^{\mathrm{a}}$} \\
\hline \multirow[t]{2}{*}{ Model } & \multicolumn{2}{|c|}{ Unstandardized Coefficients } & Stand a rdized & T & \\
\hline & $B$ & Std. Error & Beta & & \\
\hline (Constant) & 094 & .009 & & & \\
\hline Beda Permanen &, 050 &, 106 & & & \\
\hline 1 Beda Temporer &,- 541 & ,262 & & $-2,06$ & \\
\hline Ukuran Perusahaan & $-3,522 E-009$ &, 000 & & $-10,57$ & .000 \\
\hline RTBlt & $5,305 \mathrm{E}-008$ & & & 23,25 &, 000 \\
\hline
\end{tabular}

Berdasarkan tabel 4.7 diatas dapat diketahui bahwa nilai sig untuk variabel Perbedaan Permanen $0,641>0,05$. Nilai sig untuk variabel Perbedaan Temporer $0,041<0,005$.Nilai sig untuk variabel Ukuran Perusahaan $0,000<0,005$. Nilai sig untuk variabel Laba Sebelum Pajak Tahun Berjalan 0,000 $<0,005$, karena nilai sig dari masing-masing variabel lebih besar dari 0,05 maka dapat disimpulkan bahwa model regresi bebas dari heteroskedastistas yang ditunjukkan oleh gambar Scatterplot berikut:

\section{GAMBAR 4.2}

\section{Gambar Scatterplot}

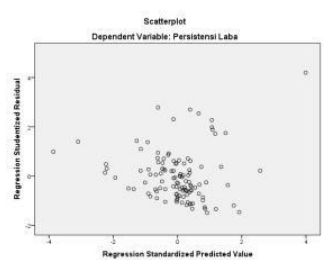

Sumber: Data diolah SPSS 21, 2017

\section{Analisis Regresi Linier Berganda}

TABEL 4.8

\section{Hasil Regresi Linear Berganda}

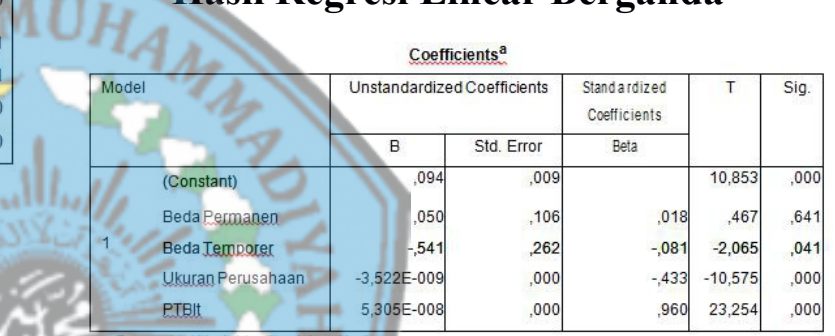

Sumber: Data diolah SPSS 21, 2017

Berdasarkan tabel 4.8 diatas diperoleh hasil persamaan model regresi linier berganda sebagai berikut:

Persistensi Laba $=10,853+$

$$
0,467 \mathrm{X} 1-2,065 \mathrm{x} 2-10,575 \mathrm{X} 3+23,254 \mathrm{X} 4
$$$$
+\varepsilon
$$

\section{Uji Hipotesis}

\section{Uji t (Uji Parsial)}

Hasil dari uji parsial yang dilakukan dengan menggunakan bantuan SPSS 21 dapat dilihat pada tabel dibawah ini: 
TABEL 4.9

\section{Hasil Uji-t}

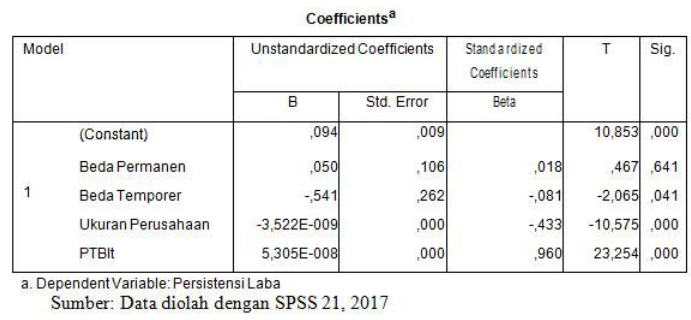

Dari tabel 4.9 diatas nilai konstanta menunjukkan bahwa besarnya persistensi laba 0,094 tanpa dipengaruhi oleh perbedaan permanen, perbedaan temporer, ukuran perusahaan dan laba sebelum pajak tahun berjalan. Nilai $t$ hitung konstanta sebesar 10,852 dengan signifikansi sebesar $0,000<0,05$, maka nilai konstanta signifikan untuk memprediksi persistensi laba tanpa pertimbangan perbedaan permanen, perbedaan temporer, ukuran perusahaan dan laba sebelum pajak tahun berjalan. signifikansi sebesar 0,041<0,05 maka nilai koefisien perbedaan temporer berpengaruh signifikan kearah negatif terhadap persistensi laba perusahaan manufaktur yang terdaftar di BEI.

Nilai $\mathrm{t}$ hitung koefisien ukuran perusahaan sebesar $-10,575$ dengen signifikansi sebesar $0,000<0,05$ maka nilai koefisien ukuran perusahan berpengaruh signifikan kearah negatif terhadap persistensi laba perusahaan manufaktur yang terdaftar di BEI.

Nilai t hitung koefisien laba sebelum pajak tahun berjalan sebesar 23,254 dengan signifikansi sebesar $0,000<0,05$ maka nilai koefisien laba sebelum pajak tahun berjalan berpengaruh signifikan terhadap persistensi laba perusahaan manufaktur yang terdaftar di BEI.

\section{Uji F (Uji Simultan)}

Dari tabel 4.9 diatas nilai $\mathrm{t}$ hitung koefisien perbedaan permanen sebesar 0,467 dengan signifikansi sebesar 0,641> TABEL 4.10 Hasil Uji-F (Uji Simultan) 0,05, maka nilai koefisien perbedaan permanen tidak berpengaruh signifikan positif terhadap persistensi laba perusahaan manufaktur yang terdaftar di BEI.

Nilai t hitung koefisien perbedaan temporer sebesar -2,065 dengan

\begin{tabular}{|c|c|c|c|c|c|}
\hline \multicolumn{6}{|c|}{ ANOVA $^{\mathrm{a}}$} \\
\hline Model & Sum of Squares & df & Mean Square & $\mathrm{F}$ & Sig. \\
\hline Regression & 2,152 & 4 & ,538 & 137,933 &, $000^{\mathrm{b}}$ \\
\hline 1 Residual & ,468 & 120 & .004 & & \\
\hline Total & 2,620 & 124 & & & \\
\hline
\end{tabular}

Berdasarkan hasil uji $\mathrm{F}$ pada tabel 4.10 diatas menunjukkan nilai $\mathrm{F}$ sebesar 137,933 dengan signifikansi sebesar 
0,000. Nilai probabilitas signifikansi pengujian tersebut lebih kecil dari alpha 0,05, maka dapat disimpulkan bahwa terdapat pengaruh yang signifikan antara perbedaan permanen, perbedaan temporer, ukuran perusahaan dan laba sebelum pajak tahun berjalan terhadap persistensi laba perusahaan manufaktur yang terdaftar di BEI tahun 2011-2015.

\section{Uji Koefisien Determinasi}

TABEL 4.11

Hasil Uji Koefisien Determinasi (R2)

Dari tabel 4.11 diatas dapat dilihat bahwa nilai koefisien determinasi (RSquare) adalah sebesar $82,1 \%$. Hal ini menunjukkan bahwa $82,1 \%$ persistensi labaperusahaan manufaktur dipengaruhi oleh perbedaan permanen, perbedaan temporer, ukuran perusahaan dan laba sebelum pajak tahun berjalan. Sisanya sebesar $17,9 \%$ dipengaruhi oleh variabel lain diluar variabel dalam penelitian ini.

\section{PEMBAHASAN}

PengaruhPerbedaanPermanenTer hadapPersistensiLabaPerusahaanManu faktur

Perbedaan permanen yang tidak berpengaruh secara signifikan terhadap persistensi laba merupakan dampak dari jumlah perbedaan permanen yang tidak terlalu signifikan besarnya terhadap jumlah laba kena pajak (penghasilan kena pajak). Perbedaan permanen yang dapat menjadi pengurang atau penambah laba kena pajak dengan jumlah yang tidak signifikan tidak akan terlalu berpengaruh terhadap perubahan jumlah beban pajak kini.

\section{Pengaruh}

Perbedan temporer yang berpengaruh negatif secara signifikan terhadap pertumbuhan laba merupakan dampak dari jumlah perbedaan temporer yang terdapat dalam laba fiskal (penghasilan kena pajak). Koefisien perbedaan temporer yang menunjukkan angka negatif artinya perbedaan temporer itu akan menjadi pengurang dan memberikan pengaruh negative terhadap persistensi laba.

\section{Pengaruh Ukuran Perusahaan}

Terhadap Persistensi Laba Perusahaan

\section{Manufaktur}


Semakin besar ukuran perusahaan maka akan semakin memperkecil perusahaan didalam melakukan tax planning dan mengatur keuangan perusahaan. Tax planning dianggap sebagai aspek penting dalam book-tax differences.

\section{Pengaruh Laba Sebelum Pajak}

\section{Tahun Berjalan Terhadap Persistensi}

\section{Laba Perusahaan Manufaktur}

Laba sebelum pajak tahun berjalan yang melemah akan menyebabkan kualitas laba yang buruk dan merendahkan persistensi laba dimasa datang, begitu juga sebaliknya jika laba sebelum pajak tahun berjalan meningkat maka akan menyebabkan kualitas laba menjadi baik dan menaikkan persistensi laba dimasa datang.

\section{KESIMPULAN DAN SARAN}

\section{Kesimpulan}

1. Variabel perbedaan permanen tidak berpengaruh positif terhadap persistensi laba perusahaan manufaktur yang terdaftar di Bursa Efek Indonesia tahun 2011-2015.

2. Variabel perbedaan temporer berpengaruh secara negatif terhadap persistensi laba perusahaan manufaktur yang terdaftar di Bursa Efek Indonesia tahun 2011-2015.

3. Variabel ukuran perusahaan berpengaruh negatif terhadap persistensi laba perusahaan manufaktur yang terdaftar di Bursa Efek Indonesia tahun 2011-2015.

4. Variabel laba sebelum pajak tahun berjalan berpengaruh terhadap persistensi laba perusahaan manufaktur yang terdaftar di Bursa Efek Indonesia tahun 2011-2015.

5. Berdasarkan hasil uji F (uji simultan) terdapat pengaruh yang signifikan antara perbedaan permanen, perbedaan temporer, ukuran perusahaan dan laba sebelum pajak tahun berjalan terhadap persistensi laba perusahaan manufaktur yang terdaftar di BEI tahun 2011-2015.

\section{Saran}

1. Penelitian selanjutnya diharapkan dapat menggunakan sampel yang berbeda (memperluas sampel).

2. Untuk para pemakai laporan keuangan dan laporan tahunan, agar lebih mewaspadai perbedaan besar antara laba akuntansi dan laba fiskal yang menerminkan kualitas laba yang dilaporkan. 
3. Agar penelitian selanjutnya

memasukkan asumsi bahwa tidak terdapat perusahaan yang melakukan merger atau akuisisi dalam sampel penelitian.

\section{DAFTAR PUSTAKA}

Astika, Ida, Putra. 2010. Teori Akuntansi Konsep-konsep Dasar Akuntansi Keuangan.Diktat Kuliah pada Fakultas Ekonomi Universitas Udayana.

Belkaoui, Ahmed. 2007. Accounting Theory Teori Akuntansi Buku Dua, Salemba Empat :Jakarta.

Chandrarin.2003. Laba (Rugi) Selisih Kurs sebagai Salah Satu Faktor yang Mempengaruhi Koefisien Respon Laba Akuntansi: Bukti Empiris dari Pasar Modal Indonesia. Disertasi. Yogyakarta: Universitas Gajah Mada.

Chowijaya, Andriansyah. 2014. Pengaruh Laba Akuntansi, Laba Fiskal dan Arus Kas Operasi Terhadap Persistensi Laba. STIE Multi Dana Palembang.

Dewi, Putu dan Putri. 2015. Pengaruh Book-Tax Differences, Arus Kas Operasi, Arus Kas Akrual dan Ukuran Perusahaan pada Persistensi Laba. E-jurnal AkuntansiUniversitas Udayana, 10.1. 2015: 244-260. ISSN: 2302-8556.

Djamaluddin, Handayani dan Rahmawati.2008. Analisis Pengaruh Perbedaan antara Laba Akuntansi dan Laba Fiskal Terhadap Persistensi Laba, Akrual dan Arus Kas pada Perusahaan Perbankan yang Terdaftar di Bursa Efek Jakarta.Jurnal RisetAkuntansi Indonesia, 11 (1), pp: 52-74.
Etteredge, Michael. 2008. Is Earnings Fraud Associated with High Deffered Tax and orBook Minus Tax Levels.Journal of Parctice and Theory, 27 (1). pp: 1-33.

Fajri, Achmad dan Mayangsari.2012. Pengaruh Perbedaan Laba Akuntansi dan Laba Pajak Terhadap Manajemen Laba dan Persistensi Laba.Media Riset Akuntansi,Auditing \& Informasi, Volume 12, Nomor. 1, April 2012. ISSN: 24429708 .

Fanani.2010. Analisis Faktor-faktor Penentu Persistensi Laba.Jurnal AkuntansiKeuangan Indonesia.

Ghozali, Imam. 2011. Aplikasi Analisis Multivariate dengan Program SPSS. Semarang:Badan Penerbit Universitas Diponegoro.

Gunadi.2009. Akuntansi Pajak sesuai dengan Undang-undang Pajak Baru.

Jakarta:Grasindo.

Hanlon. 2005. The Persistence and Pricing of Earnings, Accruals and Cash FlowsWhen Firm Have Large Book-Tax Differences. The Accounting Review 80 (March).pp: 137-166.

Harnanto. 2003. Akuntansi Perpajakan. Edisi Pertama. Yogyakarta: BPFE.

Ikatan Akuntan Indonesia. 2009.

Standar Akuntansi Keuangan. Jakarta:

IAI.

Ikatan Akuntan Indonesia. 2015. Standar Akuntansi Keuangan. Jakarta: IAI.

Jackson, Mark. 2009. Book-Tax Differences and Earnings Growth. Working Paper:

University of Oregon.

Karim,Abdul. 2014. Modul Praktikum Pengantar Metode Statstika. Universitas Muhammadiyah Semarang. 
Kiswara, E. 2011.Akuntansi

Perpajakan. BP UNDIP. Semarang.

Nurbaiti, Salsabilla dan Pratomo. 2016. Pengaruh Book-Tax Differences dan Aliran Kas Operasi Terhadap Persistensi Laba. Jurnal Akuntansi. Vol. XX, No. 02. Mei 2016: 314-329.

Palepu, Bernard, dan Healy. 2000. Business Analysis and Valuation: Using FinancialStatement. South-Western.

Panjaitan, Yunia, Dewinta dan Sri Desinta. 2004. Analisis Harga Saham, Ukuran Perusahaan dan Resiko Terhadap Return yang Diharapkan Investor pada Perusahaan Saham Aktif. Balance, 1 (1), h: 56-72.

Persada, Aulia Eka dan Dwi. 2010. Analisis Faktor yang Mempengaruhi Book-Tax Gap dan Pengaruhnya Terhadap Persistensi Laba.Jurnal Akuntansi dan KeuanganIndonesia.Volume 7-No. 2.Desember 2010. ISSN: 2406-9701.

Pertiwi, Intan dan Zulaikha. 2014. Analisis PengaruhBook-Tax Differences pada

Persistensi Laba. Diponegoro journal of accounting.Vol. 3, No. 3 Tahun 2014.

ISSN: 2337-3806.

Phillips, John, Marton dan Sonja. 2003. Earnings Management: New Evidence Based

on Deferred Tax Expense. The Accounting Review. Vol 78: 491-521.

Resmi, Siti. 2011. Perpajakan: Teori dan Kasus Buku 1 Edisi 6. Jakarta: Salemba Empat.

Santoso, Singgih. 2000. SPSS Versi 10 Mengolah Data Statistik Secara Profesional. PT Elex Media Komputindo Gramedia, Jakarta.
Saputro. 2011. Pengaruh Book-Tax Differences Terhadap Pertumbuhan Laba (Studi Empiris pada Perusahaan Manufaktur yang Terdaftar di Bursa Efek Indonesia tahun 2008-2010. Semarang: BP UNDIP.

Schipper. 1989. Earnings Management. Accounting Horizons 3, 91-106.

Suandy, Erly. 2001. Perencanaan Pajak. Jakarta: Salemba Empat.

Subramanyam, Wild dan John. 2008. Analisis Laporan Keuangan. Jakarta: Salemba Empat.

Subramanyam, Wild, John. 2010.

Analisis Laporan Keuangan. Jakarta: Salemba Empat.

Sugiyono. 2012. Metode Penelitian Kuantitatif dan R\&D. Bandung: Alfabeta.

Suwandika,Ida Bagus. 2013. Pengaruh Perbedaan Laba Akuntansi, Laba Fiskal, Tingkat Hutang pada Persistensi Laba.E-jurnal Akuntansi Universitas Udayana5.1. ISSN: 23028556.

Wijayanti, Handayani Tri. 2006. Analisis Pengaruh Perbedaan antara Laba Akuntansi dan Laba Fiskal terhadap Persistensi Laba, Akrual dan Arus Kas, Jurnal, Padang:Simposium Nasional Akuntansi 9.

Undang-undang Republik Indonesia Nomor 36 Tahun 2008 tentang Pajak Penghasilan.

www.idx.co.id

Zain. 2008. Manajemen Perpajakan. Salemba Empat. Jakarta. 